УДК 343.211

DOI https: / / doi.org/10.32837 / yuv.v0i1.1644

\author{
В. Савицька,
}

аспірантка кафедри кримінального права та кримінології

Дніпропетровського державного університету внутрішніх справ

\title{
ДОСВІД ОКРЕМИХ КРАЇН ПОСТРАДЯНСЬКОГО ПРОСТОРУ ЩОДО ВИКОРИСТАННЯ ПОНЯТТЯ «ЗАВІДОМІСТЬ»У ЗАГАЛЬНИХ ЧАСТИНАХ КРИМІНАЛЬНИХ КОДЕКСІВ
}

Конституція України у ст. 62 проголосила, що особа вважається невинуватою у вчиненні злочину і не може бути піддана кримінальному покаранню, доки іï вину не буде доведено в законному порядку i встановлено обвинувальним вироком суду. Ніхто не зобов'язаний доводити свою невинуватість у вчиненні злочину. Обвинувачення не може грунтуватися на доказах, одержаних незаконним шляхом, а також на припущеннях. Усі сумніви щодо доведеності вини особи тлумачаться на іï користь.

Наведене положення Основного Закону відображене у ч. 2 ст. 2 Кримінального кодексу (далі - KK) України, ст. 2, ст. 17 та п. 2 ч. 1 ст. 91 Кримінального процесуального кодексу (далі - КПК) України, що має максимально сприяти реалізації такої конституційної норми. У свою чергу, вина є обов'язковою ознакою суб'єктивної сторони складу злочину, встановлення якої $є$ завершальним етапом у констатації складу злочину як єдиної підстави кримінальної відповідальності, тому їі з'ясування має важливе значення.

Традиційно крім вини до ознак суб'єктивної сторони складу злочину відносять мотив, мету й емоційний стан. Водночас у КK України зустрічаються й інші ознаки, визначені законодавцем як обов'язкові, що розкривають зміст суб'єктивної сторони складу злочину. Йдеться про завідомість, яку з метою конкретизації вини використовують як ознаку складу злочину більше, ніж у 30 статтях Особливої частини $\mathrm{KK}$ України. У Загальній частині КК Украіни завідомість $є$ ознакою невиправданого ризику (ч. 3 ст. 42) та обставиною, що обтяжує покарання (п. 7 ч. 1 ст. 67 ).

Теоретичним i практичним підгрунтям дослідження проблеми завідомості у кримінальному праві стали роботи відомих вітчизняних i зарубіжних вчених у галузі кримінального, кримінально-виконавчого права та кримінології, зокрема Ю.В. Бауліна, О.М. Бандурки, Р.В. Вереши, П.А. Вороб'я, В.К. Грищука, В.В. Голіни, О.М. Джужі, В.М. Дрьоміна, Т.А. Денисової, В.П. Ємельянова, О.О. Книженко, В.А. Кирилюк, О.Г. Колба, І.М. Копотуна, О.М. Костенка, О.М. Литвинова, О.М. Литвака, М.I. Мельника, П.П. Михайленка, С.С. Мірошниченка, B.O. Навроцького, В.I. Осадчого, M.I. Панова, А.В. Савченка, В.В. Сташиса, Є.Л. Стрельцова, В.Я. Тація, В.П. Тихого, П.Л. Фріса, В.В. Шаблистого, Н.М. Ярмиш, С.С. Яценка та ін. Окремо слід відзначити докторську дисертацію Р.В. Вереши (2017) «Проблеми суб'єктивної сторони складу злочину», у якій він пише про вчинення злочинів із необережності, ознакою яких є завідомість.

Відзначаючи безперечну значущість раніше проведених досліджень, зауважимо, що вони не вичерпують кола питань, які вимагають вирішення. Це стосується і досвіду окремих країн пострадянського простору щодо використання поняття «завідомість» 
у загальних частинах кримінальних кодексів.

Інтерес юристів до іноземних правових систем і міжнародного права сьогодні є високим як ніколи. В останнє десятиліття не лише в Україні, але й у цілому світі дедалі більше і більше робіт у юридичній науці присвячуються порівняльним дослідженням. Таку тенденцію можна пов'язати із глобалізацією, уніфікацією права, розвитком міжнародної торгівлі та боротьби із міжнародною злочинністю, різноманітними інтеграційними процесами [1, с. 115].

Крім того, дослідження кримінально-правового досвіду іноземних держав дозволяє виокремити ряд переваг i недоліків, які доречно впровадити (або навпаки, слід уникнути надалі) у вітчизняний KK.

Слушними з цього приводу виглядають роздуми О.С. Кузембаєва про те, що вивчення розвитку кримінального права зарубіжних країн дає можливість використовувати накопичений раніше досвід цих країн із метою подальшого використання в Україні при здійсненні реформування й удосконалення вітчизняного кримінального права [2, с. 699].

$\mathrm{У}$ контексті предмета нашого дослідження аналіз кримінального законодавства зарубіжних країн виглядає вельми актуальним, адже така робота дозволить встановити зміст, що вкладається в поняття «завідомість» в іноземних нормативно-правових актах, простежити необхідність і послідовність його використання та порівняти 3 аналогічними положеннями КК України.

Тож, як зазначає Ю.Б. Курилюк, наукове осмислення позитивного зарубіжного досвіду сприятиме вдосконаленню національних кримінально-правових норм, а також дозволить уникнути помилок при вирішенні проблемних питань у вітчизняному праві [3, с. 802].

Перш ніж розглянути зарубіжний досвід використання у кримінальному законодавстві поняття завідомості, зауважимо, що найбільш ефективним вбачається дослідження досвіду пострадянських країн, адже в них, враховуючи спільний історичний період розвитку, місце завідомості у суб'єктивній стороні кримінального правопорушення та розуміння змісту цієї ознаки максимально наближене до вітчизняного. Використання для порівняння законодавства інших зарубіжних країн у цьому конкретному випадку вбачається менш ефективним, як мінімум, із двох причин: по-перше, враховуючи складності й особливості перекладу, під час дослідження можуть бути стерті межі, що існують між такими категоріями, як «завідомість», «обізнаність», «умисел», «свідомість» тощо, а, по-друге, через деяку специфіку (насамперед мовну та правову) окремих держав поняття «завідомості» взагалі може замінюватися іншими, схожими за значеннями термінами.

Розпочнемо наш аналіз із кримінального законодавства Азербайджанської Республіки. KK цієї держави вступив у законну силу на рік раніше вітчизняного закону про кримінальну відповідальність - 1 вересня 2000 р. $\mathrm{У}$ цьому законодавчому акті законодавець 63 рази згадує поняття «завідомість»: 4 рази в Загальній частині та 59 в Особливій.

Розглянемо випадки вживання поняття завідомості у змісті Загальної частини KK Азербайджанської Республіки. Перша згадка ознаки завідомості міститься у ст. 39 «Виправданий ризик». Так, цей термін вживається у словосполученні «ризик не визнається виправданим, якщо він завідомо був пов'язаний із загрозою для життя людей...» [4].

Зрозуміло, що в цьому разі ознака завідомості стосується фактичного характеру дій суб’єкта злочину, який не просто припускає, що його ризик пов'язаний із загрозою для життя людей, а повністю впевнений у цьому.

У ст. 40 КК Азербайджанської Республіки «Виконання наказу або розпорядження» ознака завідомості згадується двічі: «виконання завідомо незаконних 
наказу або розпорядження», «невиконання завідомо незаконних наказу або розпорядження виключає кримінальну відповідальність» [4].

Таким чином, завідомість у наведеній нормі також означає повне розуміння підпорядкованою особою факту незаконності наказу (тобто усвідомлення, що він порушує законодавчі норми).

Зустрічається завідомість і у ст. $61 \mathrm{KK}$ Республіки Азербайджан «Обставини, які обтяжують покарання» один раз у словосполученні «вчинення злочину щодо жінки, котра завідомо для винного перебуває у стані вагітності» [4].

В означеному випадку завідомість стосується характеристики потерпілої особи (конкретно іï стану - вагітності). Нагадаємо, що завідомість у такому зв'язку використовувалася ще в нормативно-правових актах Російської імперії.

У КK сусідньої Республіки Білорусь категорія «завідомість» вживається набагато частіше - 125 разів.

Думається, окрему увагу слід приділити ст. 4 «Роз'яснення окремих термінів Кримінального кодексу». Так, у ч. 14 вказується, що під терміном «завідомо» розуміється ознака, яка вказує, що особі, котра вчиняє злочин, відомі юридично значущі обставини, передбачені цим КK [5].

Отже, на відміну від КК України та розглянутого вище закону про кримінальну відповідальність Азербайджанської Республіки, законодавець Республіки Білорусь на законодавчому рівні закріпив визначення цієї ознаки, що, без сумніву, є перевагою цього нормативно-правового акта.

Враховуючи наведене, вважаємо за доцільне перейняти досвід нашого північного сусіда та закріпити в Загальній частині КK України визначення поняття «завідомо».

Загалом же ознака завідомості зустрічається в Загальній частині КK Республіки Білорусь ще 8 разів. Із них двічі вона стосується фактичного характеру дій суб’єкта кримінального правопорушення:
1. У п. 19 ч. 2 ст. 27 «Вік, із якого настає кримінальна відповідальність» у словосполученні «завідомо неправдиве повідомлення про небезпеку» [5].

Відповідно до названої вище ст. 4 завідомість означає, що суб'єкт злочину, повідомляючи про небезпеку, розуміє, що зміст цього повідомлення не відповідає об'єктивній дійсності.

2. У Ч. 3 ст. 39 «Діяння, пов'язане з ризиком» - у словосполученні «ризик, не визнається виправданим, якщо він завідомо був пов'язаний із загрозою екологічної катастрофи, суспільного лиха, настання смерті або заподіяння тяжкого тілесного ушкодження особі» [5].

Схожа норма була розглянута вище під час аналізу положень KK Азербайджанської Республіки.

Двічі ознака завідомості стосується правового значення вчинюваних дій. Обидва випадки зустрічаються у ст. 40 «Виконання наказу або розпорядження»: у ч. 2 зустрічається поняття «завідомо злочинний наказ», а у ч. 3 - «завідомо незаконний» [5].

Таким чином, у KK Республіки Білорусь, як і в KK Азербайджанської Республіки також зустрічається поняття завідомо незаконного (ст. 40 KK Азербайджанської Республіки) та завідомо злочинного наказів (ст. 117 KK Азербайджанської Республіки). Таке рішення законодавця певною мірою порушує принцип єдності юридичної термінології, через що, на нашу думку, доцільним було б обрати єдиний термін (наприклад, «незаконний», адже він має більш широке значення).

Чотири рази завідомість стосується характеристики потерпілих від злочину. Всі вони передбачені ст. 64 «Обставини, що обтяжують відповідальність» у словосполученнях «щодо завідомо малолітнього, особи похилого віку або особи, що перебуває у безпорадному стані», «щодо завідомо для винного вагітної жінки», «використання злочину з використанням завідомо малолітнього або особи, яка завідомо для 
винного страждає психічним розладом (хворобою)» [5].

Нагадаємо, ознака завідомості в KK Азербайджанської Республіки найбільш часто стосувалася саме перших трьох категорій осіб, котрі виступали потерпілими від злочину.

Отже, у KK Республіки Білорусь ознака завідомості досить поширена. Суттєвою перевагою KK Республіки Білорусь вбачається наявність законодавчого визначення поняття завідомості. Здебільшого в нормах цього законодавчого акта завідомість використовується саме в цьому значенні та стосується таких ознак, як суспільно небезпечне діяння, предмет злочину або потерпіла від злочину особа.

У змісті КK Республіки Вірменія ознака завідомості зустрічається значно рідше - 54 випадки: 5 - у Загальній частині та 49 - в Особливій.

У Загальній частині категорія «завідомість» міститься в таких нормах:

1. Ч. 1 ст. 46 «Виправданий ризик», у якій вказано: «Ризик не визнається виправданим, якщо він завідомо був пов'язаний із небезпекою загибелі третіх осіб, із загрозою екологічної катастрофи або суспільного лиха» [6].

Ця норма є майже ідентичною ст. 39 KK Азербайджанської Республіки та ст. 39 KK Республіки Білорусь.

2. Двічі ознака завідомості згадується у диспозиції ст. 47 «Виконання наказу або розпорядження: у ч. 2 завідомо незаконний наказ або розпорядження - та у ч. 3 - завідомо неправильний наказ або розпорядження [6].

Нагадаємо, що в Загальній частині KK Азербайджанської Республіки та Республіки Білорусь також містяться схожі норми (ст. 40 в кожному з цих нормативно-правових актів), проте в першому документі згадується «незаконний наказ або розпорядження», у другому - «незаконний і злочинний», а в KK Республіки Вірменія - «незаконний та неправильний». Думається, остання категорія, враховуючи той факт, що в самому законодавчому акті не розкривається зміст цього поняття, виглядає дещо незрозумілою, через що під час кваліфікації дій особи можуть виникнути проблеми.

3. Двічі у ст. 63 «Обставини, які обтяжують відповідальність і покарання»: у п. 5 (залучення до вчинення злочину осіб, котрі завідомо для винного страждають хворобливими психічними розладами) й у п. 8 (вчинення злочину щодо жінки, яка є для винного завідомо вагітною) [6].

У кожному з цих випадків завідомість стосується характеристики потерпілої від злочину особи.

У KK Грузіі поняття «завідомість» згадується 56 разів. У Загальній частині воно вживається лише у єдиному випадку - у ч. 2 ст. 37 «Виконання наказу або розпорядження» у словосполученні «завідомо злочинний наказ або розпорядження» [7].

В Особливій же частині ознака завідомості є більш розповсюдженою. Як і в розглянутих вище документах, у цьому законодавчому акті завідомість в багатьох випадках стосується ознаки характеристики потерпілої від злочину особи. У цілому ряді норм КК Грузіі завідомість вживається декілька разів і стосується різних характеристик потерпілих від злочину особи (різних потерпілих). Зокрема, подібні випадки зустрічаються у таких нормах: двічі у ст. 109 «Умисне вбивство 3 обтяжуючими обставинами» (згадується потерпіла особа - жінка, яка завідомо для винного перебувала у стані вагітності, та завідомо неповнолітній), двічі у ст. 117 «Умисне заподіяння тяжкої шкоди здоров'ю» (згадуються такі потерпілі, як жінка, котра завідомо для винного перебуває у стані вагітності, та завідомо неповнолітній), двічі у ст. 126 «Насильство» (у п. «б» ч. 2 у словосполученні «щодо жінки, яка завідомо для винного перебуває у стані вагітності» Й у П. «Г» ч. 2 у словосполученні «щодо завідомо для винного неповнолітнього», двічі у ст. 137 «Згвалтування» (згадуються такі потерпілі, як жінка, котра завідомо для винного перебуває у стані вагітно- 


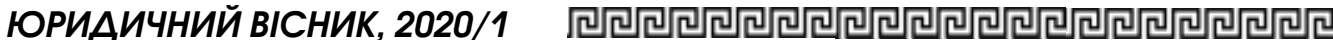

сті, та завідомо неповнолітній), двічі у ст. 138 «Насильницькі дії сексуального характеру» (жінка, яка завідомо для винного перебуває у стані вагітності, та завідомо неповнолітній), двічі у ст. 143-1 «Торгівля людьми» (у п. «а» ч. 2 у словосполученні «щодо жінки, котра завідомо для винного перебуває у стані вагітності» Й у П. «б» Ч. 2 «щодо особи, яка завідомо для винного перебуває у безпорадному стані або матеріально чи іншим чином залежить від винного»), двічі у ст. 143-2 «Торгівля неповнолітніми» (у п. «а» ч. 2 у словосполученні «щодо жінки, що завідомо для винного перебуває у стані вагітності» Й у П. «б» Ч. 2 - «щодо особи, яка завідомо для винного перебуває у безпорадному стані або матеріально чи іншим чином залежить від винного»), двічі у ст. 143-3 «Користування послугами жертв (потерпілих) торгівлі людьми» (згадується завідомо вагітна й особа, котра завідомо для винного перебуаає у безпорадному стані) [7].

Варто зауважити, що у всіх цих випадках законодавець окремо вживає ознаку завідомості 3 кожною ознакою характеристики потерпілого (у цьому разі стан і вік потерпілої особи). Такий крок виглядає цілком логічним і свідчить про те, що для притягнення особи до кримінальної відповідальності за вчинення цих кримінальних правопорушень необхідно довести, що їй було добре відомі відповідні об’єктивні ознаки.

Як слушно вказує П.І. Орлов, усвідомлення особою цієї ознаки як можливої або ймовірної не дає підстави визнати ї явною для винного і, отже, виключає наявність у його діях відповідного складу злочину [8, с. 7].

Більш того, повністю підтримуємо В.В. Шаблистого з приводу того, що корупція 3 необережності в Україні можлива - за незначні необережні порушення антикорупційного законодавства відповідних суб'єктів варто притягувати виключно до дисциплінарної відповідальності за корупційні або пов'язані з корупцією правопорушення, оскільки їхне законодавче визначення допускає необережну форму вини [9, с. 233], оскільки це свідчить про неможливість існування завідомо необережних злочинів.

Отже, у КK Грузії ознака завідомості здебільшого вживається в єдиному значенні (повне усвідомлення суб'єктом злочину відповідних об'єктивних ознак), втім, нами зафіксовано і кілька випадків відхилення від цього значення, що свідчить про порушення принципу єдності юридичної термінології.

Загалом у KK Грузії ознака завідомості стосується ознак характеристики потерпілого від злочину (зазвичай віку та стану). Втім, у цьому питанні виявлена певна непослідовність у нормах, які передбачають одразу декілька спеціальних потерпілих (наприклад, завідомість стосується потерпілої від кримінального правопорушення вагітної жінки - та не поширюється на неповнолітнього).

На відміну від КК України та розглянутого вище закону про кримінальну відповідальність Азербайджанської Республіки, законодавець Республіки Білорусь на законодавчому рівні закріпив визначення цієї ознаки, що, без сумніву, є вагомою перевагою цього нормативно-правового акта.

Таким чином, у КK Республіки Білорусь, як і в KK Азербайджанської Республіки також зустрічається поняття завідомо незаконного (ст. 40 KK Азербайджанської Республіки) та завідомо злочинного наказів (ст. 117 KK Азербайджанської Республіки). Таке рішення законодавця певною мірою порушує принцип єдності юридичної термінології, через що, на нашу думку, доцільним було б обрати єдиний термін (наприклад, «незаконний», адже він має більш широке значення).

У KK Республіки Білорусь ознака завідомості досить поширена. Суттевою перевагою КК Республіки Білорусь вбачається наявність законодавчого визначення поняття завідомості. Здебільшого в нормах цього законодавчого акта за відомість використовується 
саме в цьому значенні та стосується таких ознак, як суспільно небезпечне діяння, предмет злочину або потерпіла від злочину особа.

У статті в межах підготовки дисертаціі за темою: "Поняття завідомості за кримінальним правом України» узагальнено досвіо окремих країн пострадянського простору щодо використання поняття «завідомість» у загальних частинах кримінальних кодексів.

Встановлено, щз в КК Грузії ознака завідомості здебільшого вживається в єоиному значенні (повне усвідомлення суб'єктом злочину відповідних об'єктивних ознак), втім, нами зафіксовано $і$ кілька випадків відхилення від цього значення, щз свідчить про порушення принципу єдності юридичної термінологї. Загалом у КК Грузї ознака завідомості стосується ознак характеристики потерпілого від злочину (зазвичай віку та стану). Втім, у иьому питанні виявлена певна непослідовність в нормах, які передбачають одразу декілька спеціальних nотерпілих (наприклад, завідомість стосується потерпілої від кримінального правопорушення - вагітної жінки - та не поширюеться на неповнолітнього).

На відміну від КК України та розглянутого вище закону про кримінальну відповідальність Азербайджанської Республіки, законодавець Pеспубліки Білорусь на законодавчому рівні закріпив визначення иієї ознаки, що, без сумніву, є вагомою перевагою иього нормативно-правового акта.

У КК Республіки Білорусь, як $i$ в КК Азербайджанської Республіки також зустрічається поняття завідомо незаконного (cm. $40 \mathrm{KK}$ Азербайджанської Республіки) та завідомо злочинного наказів (cm. 117 КК Азербайджанської Республіки). Таке рішення законодавия певною мірою порушує принщии єдності юридичної термінологї, через щуо, на нашу думку, доцільним було б обрати єдиний термін (наприклад, «незаконний», адже він має більш широке значення).

У KК Республіки Білорусь ознака завідомості досить поширена. Cуттевою перевагою КK Республіки Білорусь є наявність законодавчого визначення поняття завідомості. Здебільшого у нормах изього законодавчого акта завідомість використовується саме в иьому значенні та стосується таких ознак, як суспільно небезпечне діяння, предмет злочину або потерпіла від злочину особа.

Ключові слова: свідомість, завідомість, злочин, покарання, кримінальне право, суб'єктивна сторона складу злочину.

Savytska V. Experience of some countries of the former Soviet Union on the use of the concept of "awareness" in the general parts of the criminal codes

In the article, within the framework of preparation of the dissertation on the topic: "The concept of awareness under the criminal law of Ukraine" summarizes the experience of some countries of the former Soviet Union on the use of the concept of "awareness" in the general parts of the criminal codes.

It has been established that in the Criminal Code of Georgia the majority of cases of awareness is used in a single sense (full awareness of the subject of the crime of the relevant objective features), but we have also recorded several cases of deviation from this value, which testifies to the violation of the principle of unity of legal terminology. In general, in the Criminal Code of Georgia, the sign of awareness in most cases refers to the characteristics of the victim of the crime (usually age and condition). However, this issue revealed some inconsistency in the rules, which provide for several 
special victims at once (for example, the awareness concerns a victim of a criminal offense - a pregnant woman, but does not extend to a minor).

Unlike the Criminal Code of Ukraine and the law on criminal liability of the Republic of Azerbaijan discussed above, the legislator of the Republic of Belarus has fixed the definition of this feature at the legislative level, which is undoubtedly a major advantage of this regulatory act.

In the Criminal Code of the Republic of Belarus, as in the Criminal Code of the Azerbaijan Republic, the notion of deliberately illegal (Article 40 of the Criminal Code of the Azerbaijan Republic) and deliberately criminal orders (Article 117 of the Criminal Code of the Republic of Azerbaijan) are also found. This decision of the legislator to a certain extent violates the principle of the unity of legal terminology, which, in our opinion, would be advisable to choose a single term (for example, "illegal", because it has a wider meaning).

In the Criminal Code of Belarus the sign of awareness is quite widespread. A significant advantage of the Criminal Code of the Republic of Belarus is the existence of a legislative definition of the concept of awareness. In the overwhelming majority of cases, the provisions of a given legislative act are consciously used in that sense and relate to such features as a socially dangerous act, an object of a crime or a victim of a crime.

Key words: consciousness, awareness, crime, punishment, criminal law, subjective party of crime.

\section{Література}

1. Шкодяк А.I. Поняття та значення кримінально-правової компаративістики. Науковий вісник Ужгородського національного університету. 2019. № 55 . T. 2. С. 115-119.

2. Кузембаєв О.С. Джерела кримінального права України та деяких європейських країн: порівняльний аналіз. Актуальні проблеми кримінальної відповідальності : матеріали міжнар. наук.-практ. конф., 10-11 жовт. 2013 р. / редкол. : В.Я. Тацій, В.І. Борисов та ін. Харків : Право, 2013. С. 699-701.

3. Курилюк Ю.Б. Зарубіжний досвід криміналізації порушення правил несення прикордонної служби. Актуальні проблеми кримінальної відповідальності : матеріали міжнар. наук.-практ. конф., 10-11 жовт. 2013 р. / редкол. : В.Я. Тащій, В.І. Борисов та ін. Харків : Право, 2013. С. 802-805.

4. Уголовный кодекс Азербайджанской Pecnублики. URL: http: / / wwш.constcourt.gov. az/laws / 32 (дата звернення: 12.06.2019)

5. Уголовный кодекс Республики Белаpycb URL: http:// etalonline.by/?type=tex t\&regnum $=H K 9900275 \#$ load_text_none_1_ (дата звернення: 12.09.2017).

6. Уголовный кодекс Республики Армения. URL: http://www.parliament.am/ legislation.php? ID=1349\&lang=rus\&sel=s hош\#31 (дата звернення: 04.03.2018).

7. Уголовный кодекс Грузии URL: https: / / matsne.gov.ge/ka/document / download/16426/143/ru/pdf (Jama звернення: 20.09.2017).

8. Орлов П.І. Кримінальна відповідальність за ненадання допомоги та залишення в небезпеці : лекція. Харків, 2017. $11 \mathrm{c}$.

9. Шаблистий В.В. Корупція з необережності (до проблеми встановлення вини та моменту виявлення пов'язаних із корупцією адміністративних $і$ кримінальних правопорушень). Юридичний науковий електронний журнал. 2020. № 1. С. 230-233. URL: http: //www.lsej.org.ua/1_2020/57.pdf. 